\title{
Antibacterial and Antioxidant Activities of Ethanol Extracts of Some Plants Selected from South Jordan
}

\author{
Waleed Khaled Al ani ${ }^{1}$, Ali Abdallah Alqudah ${ }^{2, *}$, Khaled. A. Tarawneh ${ }^{1}$
}

Waleed Khaled Al ani ${ }^{1}$, Ali

Abdallah Alqudah ${ }^{2, *}$, Khaled. A. Tarawneh ${ }^{1}$

'Department of Biology, Faculty of Science, Mu'tah University, JORDAN.

${ }^{2}$ Department of applied Biology, Faculty of

Science, Tafila Technical University, JORDAN.

\section{Correspondence}

\section{Ali Abdallah Alqudah}

Department of applied Biology, Faculty of Science, Tafila Technical University, JORDAN.

E-mail: ali_quda@yahoo.com

History

- Submission Date: 22-09-2020;

- Review completed: 17-11-2020;

- Accepted Date: 09-12-2020.

DOI : 10.5530/pj.2021.13.66

Article Available online

http://www.phcogj.com/v13/i2

\section{Copyright}

(C) 2021 Phcogj.Com. This is an openaccess article distributed under the terms of the Creative Commons Attribution 4.0 International license.

\section{ABSTRACT}

Three Jordanian medicinal plants; Peganum harmala (P. harmala), Geropogon hybridus (G. hybridus), and Salvia officinalis (S. officinalis) were selected from Al-karak region in order to investigate their antibacterial and antioxidant activities. The crude extract yield of all used plants were varied from $10.6 \%$ in Salvia officinalis and $15.6 \%$ in P. harmala, to $18 \%$ in G. hybridus. The antibacterial activity of these plants was carried out on four bacterial strain ( $S$. aureus, E.coli, E. aerogenes and B. subtilis). These plant ethanol extracts have effects on the gram positive strains and gram negative bacteria except $S$. officinalis did not show activity against E. Coli. The minimal inhibition concentration (MIC) of P. harmala S. officinalis and $G$. hybridus (MIC) ranged from $125 \mu \mathrm{g} / \mathrm{ml}$ to $500 \mu \mathrm{g} / \mathrm{ml}$. The ethanol crude extract of $G$. hybridus gave 10 fractions using TLC method, fraction 1,3 and 10 exhibited antibacterial activity against all bacterial strains. Their total phenolic contents were evaluated; the highest total phenol content was observed in G. hybridus with $410 \mathrm{mgGAE} / \mathrm{g}$ plant extract followed by $P$. harmala and S. officinalis with 305 and $203.7 \mathrm{mg} / \mathrm{g}$ plant extract, respectively. The antioxidant activity was estimated by using DPPH method. The highest antioxidant activity was obtained with $G$. hybridus extract and found to be $0.89 \mathrm{mg}$ Trolox/g plant extract. The lowest antioxidant activity was obtained with $S$. officinalis which was $0.53 \mathrm{mg}$ Trolox/g plant extract. The lowest $\mathrm{IC}_{50}$ (highest antioxidant activity) was observed in G. hybridus with $0.83 \mathrm{mg} / \mathrm{ml}$. Intermediate effect observed in $P$. harmala with $I C_{50} 1.1 \mathrm{mg} / \mathrm{ml}$. The lowest antioxidant activity was obtained in $S$. officinalis with $\mathrm{IC}_{50} 1.38 \mathrm{mg} / \mathrm{ml}$.

Key words: Antibacterial, Antioxidant, Ethanol Extracts, Peganum harmala.

\section{INTRODUCTION}

A large number of chemical compounds and molecules are present in plants as a primary and secondary metabolites, primary metabolites play an important role in basic life functions such as cell division, growth, respiration, storage, and reproduction ${ }^{1,2}$. Several other compounds which are not essential for the above functions are known as secondary metabolites which including alkaloids, lectins, and phenolic compounds such as lactones, tannins and flavonoids ${ }^{2,3}$.

Medicinal plants have been used in traditional medicine $e^{4,5}$. All parts of the plant, including the seeds, root, stem, leaves, and fruit, potentially contains bioactive components used as the source of medicines. There are many advantages and benefits associated with the use of medicinal plants, the main ones being their cost-effectiveness and global availability ${ }^{6-8}$.

In addition to their nutritional components, medicinal plants were used in treating a wide spectrum of diseases. Moreover, they have been screened for their potential uses as alternative remedies, food preservatives, and as antioxidants to neutralize the toxic effects of oxidants ${ }^{9,10}$. Jordan has a high flora diversity with wide traditional uses of medicinal plants as antibacterial, antioxidant, and antifungal agents ${ }^{11}$. Moreover, random screening of plants for the active chemical compounds is important as the screening of ethno botanical targeted species ${ }^{12-15}$.

Several medicinal plant species are widely distributed in Jordan ${ }^{16}$, plants, $P$. harmala, S. officinalis and $G$. hybridus, are examples of the local medicinal plants. $P$. harmala is a plant of the family Nitrariaceae belongs to Asian origin and grows in the middle east and in part of south Asia mainly in India and Pakistan ${ }^{17}$. S. officinalis is a perennial plant (subshrub), native to the Mediterranean region, belongs to the Lamiaceae family, its leaves are mainly used as a spices with established biological activity ${ }^{18}$. G. hybridus, commonly known as salsify, oyster plant, goat's beard and vegetable oyster belonging to Asteraceae family, this plant was not mentioned within the medicinal plants $^{19,20}$. Tragopogon spp which belong to the same family was mentioned to have a strong antibacterial potential ${ }^{21}$.The study was planned to investigate the efficiency of ethanol extract of the selected plants on pathogens obtained from clinical samples using standard microbiological procedures.

\section{MATERIALS AND METHODS}

The dried plant materials were collected from a local region in Alkarak, Jordan. The scientific, common, family names and parts of plant used in this study were presented in Table 1. Four bacterial strains were used in this study: S. aureus ATCC43300, E.coli ATCC25922, E. aerogenes ATCC13048 and B. subtilis

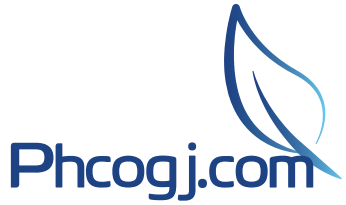

Cite this article: Alani WK, Alqudah AA, Tarawneh KA. Antibacterial and Antioxidant Activities of Ethanol Extracts of Some Plants Selected from South Jordan. Pharmacog J. 2021;13(2): 528-34 
Table 1: The botanical data of the four selected plant species used in this study.

\begin{tabular}{ccccc}
\hline$\#$ & Scientific name & Common name & Family & Parts used \\
\hline 1 & P. harmala & Harmal & Nitrariaceae & Seed \\
2 & S. officinalis & Maramiah & Lamiaceae & Arial \\
3 & G. hybridus & Haisabon & Asteraceae & Arial \\
\hline
\end{tabular}

ATCC6633. These bacterial strains were obtained from research Lab, Department of Biology, Mu'tah University.

\section{Plant processing and extraction}

The dried plant materials were ground by coffee blender into fine powder. Twenty five grams of each plant powder were soaked in 250 $\mathrm{ml}$ Ethanol solution and kept in shaker at $150 \mathrm{rpm}$, in a dark place for three days at room temperature. The mixtures were then filtrated using Buchner funnel under vacuum. The filtrate was centrifuged at $3000 \mathrm{rpm}$ for 10 minutes. The extracts were concentrated in rotary evaporator under reduced pressure at $55^{\circ} \mathrm{C}$. The extracts were left in open vials in fume hood for three days at room temperature. The resulting extracts were stored in at $4^{\circ} \mathrm{C}$ in a glass container until use $e^{22}$.

\section{Antibacterial activity of plant extracts}

Antibacterial activities of the different extracts were investigated by the disc diffusion method ${ }^{23}$. The crude plant extracts were dissolved in $10 \%$ dimethyl sulfoxide (DMSO) in addition to Methanol. Four to five well-isolated colonies of the same morphological type were selected and inoculated into tubes containing $5 \mathrm{ml}$ Muller-Hinton broth and incubated at $37^{\circ} \mathrm{C}$ with shaking at $150 \mathrm{rpm}$ until the turbidity of the bacterial growth achieved. Then the bacterial cells in the broth culture were counted using hemocytometer. A volume ranged from 0.5 to 3 $\mathrm{ml}$ of each broth culture was added to the prepared sterile nutrient agar cooled to about $45-50^{\circ} \mathrm{C}$ to obtain $2 \times 10^{6} \mathrm{cell} / \mathrm{ml}$ inoculum concentration of the organism, then poured into sterile Petri dishes and allowed to solidify for bout $45-60 \mathrm{~min}^{24}$.

For each bacterial strain, three sterile $6 \mathrm{~mm}$ antimicrobial susceptibility discs were used, the first and the second discs were loaded with $3 \mathrm{mg}$ and $4 \mathrm{mg}$ of plant extract, respectively. The third was loaded with $10 \%$ DMSO as a negative control. The discs were left to dry under aseptic conditions, then placed on the surface of the agar plate. Streptomycin $(10 \mu \mathrm{g})$ and Tetracycline $(30 \mu \mathrm{g})$ discs were used as positive controls. The plates were left on the bench for about 2 hrs to allow the extract diffuse properly into the agar. The plates were incubated for 18$24 \mathrm{hrs}$ at $37^{\circ} \mathrm{C}$. The studies were done in triplicates. Growth inhibitory activity was calculated by measuring the diameter of clear zone around the disc using a ruler ${ }^{25} .2 \times 10^{6}$ cell/mL was inoculated into tubes of 5 $\mathrm{mL}$ Muller-Hinton broth containing a serial dilution of plant extract $(0-2000 \mu \mathrm{g} / \mathrm{mL})$. Cultures were incubated at $37^{\circ} \mathrm{C}$ for $24 \mathrm{hrs}$. The MIC was determined by inhibition of visible growth on lowest concentration of plant extract containing media as comparing with visible growth on extract free media ${ }^{26}$.

\section{Antioxidant activity of plant extracts}

The DPPH radical assay was carried out as described by Tepe et al. (2005). Aliquots of various concentrations of the extracts were added to $5 \mathrm{ml}$ of $0.004 \%$ methanol solution of DPPH (The final concentration of the plant extract in the solution was from 0 to $2000 \mu \mathrm{g} / \mathrm{ml})^{27}$. After incubating the samples for $30 \mathrm{~min}$ at room temperature, the absorbance was read against methanol at $517 \mathrm{~nm}$. All determinations were done in triplicate. Inhibition of free radical scavenging activity was calculated using the following equation:
Inhibition $(\%)=100 \times\left(\mathrm{Abs}_{\text {control }}-\mathrm{Abs}_{\text {sample }}\right) / \mathrm{Abs}_{\text {control }}$

Where $\mathrm{Abs}_{\text {control }}$ is the absorbance of the control reaction (containing all reagents except the tested compound) and $\mathrm{Abs}_{\text {sample }}$ is the absorbance of the tested compound with all other reagents. Extract concentration providing $50 \%$ inhibition $\left(\mathrm{IC}_{50}\right)$ was determined from a graph plotting percentage inhibition against extract concentration.Trolox [( \pm )-6-hydroxy-2,5,7,8-tetramethylchroman-2-carboxylicacid] (final concentration 0 to $1.5 \mu \mathrm{g} / \mathrm{ml}$ ) was used as a standard for the construction of the calibration curve, and the DPPH radical-scavenging activities were expressed as mg Trolox equivalents per gram of plant extract ${ }^{28}$.

\section{RESULTS}

\section{Percentage yield of plant extracts}

The results of ethanol crude extract yield of all used plants were varied from 10.6 to $18 \%$ (Table 2).

\section{Antibacterial activity of plant extracts}

All the bacterial strains showed different response to the ethanol crude extract of $P$. harmala, S. officinalis and G. hybridus when used as antibacterial agent. The inhibition properties of all plants against the bacterial strains were increased with the increase of ethanol crude extract concentration (Tables 3-5).

Meanwhile, the ethanol extract of G. hybridus and $P$. harmala was active against $S$. aureus, B. subtilis, E. aerogenes and E.coli at both concentrations 1000 and $2000 \mu \mathrm{g} /$ disc (Table 3 and 4).While, the $S$. officinalis was active only against $S$. aureus, $B$. subtilis and E. aerogenes sat 1000 and $2000 \mu \mathrm{g} / \mathrm{disc}$, this plant was active as antibacterial agent against all of the bacterial strains with the exception of E. coli ( Table 5).

\section{Antioxidant activity}

Antioxidant activities of ethanol plant extracts were assessed by detecting their ability to scavenge the free radicals using the DPPH method.

\section{DPPH method}

DPPH radical was used for the evaluation of free radical- scavenging properties of the three plants. In order to measure the Trolox equivalent antioxidant capacity (TEAC), a Trolox standard curve was established using ten concentrations of Trolox standard solution $(0$ to $1.5 \mu \mathrm{g} / \mathrm{ml})$. The activity of ethanol plant extracts as a free radical scavenger was measured and expressed as TEAC [mg Trolox/g of plant extract] (Table 6). The results showed that $G$. hybridus the highest activity $(0.89 \mathrm{mg}$ Trolox/g of plant extract) compared with the other plants. Meanwhile, S. officinalis was the lowest ( $0.53 \mathrm{mg}$ Trolox/g of plant extract) and the intermediate effect appeared $P$. harmala $(0.67 \mathrm{mg}$ Trolox $/ \mathrm{g}$ of plant extract). These findings showed the same consequence of the TPCs.

The results of $\mathrm{IC}_{50}$ in Figure (2) showed that G. hybridus has the lowest $\mathrm{IC}_{50}$ value $(0.83 \mathrm{mg} / \mathrm{ml})$, P. harmala $\mathrm{IC}_{50}(1.1 \mathrm{mg} / \mathrm{ml})$ and $S$. officinalis with the highest $\mathrm{IC}_{50}(1.38 \mathrm{mg} / \mathrm{ml})$. These findings showed the same trend of the of the TPCs and TEAC, where, the best free radical scavenging activities reflected by the smallest $\mathrm{IC}_{50}$ values. 
Table 2: Yield of ethanol crude plant extracts [\%].

\begin{tabular}{cccc}
\hline Plants & Dry weight [g] & Weight of ethanol extract [g] & Yield of ethanol extract [\%] \\
\hline S. officinalis & 25 & 2.65 & $10.6 \%$ \\
P. harmala & 25 & 3.9 & $15.6 \%$ \\
G. hybridus & 25 & 4.5 & $18.0 \%$ \\
\hline
\end{tabular}

Table 3: Antibacterial activity of G. hybridus ethanol extract on the tested bacterial strains. Data are expressed as mean $\pm S D$, where $n=3$.

\begin{tabular}{ccc} 
Bacterial strains & \multicolumn{2}{c}{ Zone of inhibition $(\mathrm{mm})$} \\
\cline { 2 - 3 } & $\begin{array}{c}1000 \mu \mathrm{g} / \mathrm{disc} \\
\text { Mean } \pm \text { SD }\end{array}$ & $\begin{array}{c}2000 \mu \mathrm{g} / \mathrm{disc} \\
\text { Mean } \pm \text { SD }\end{array}$ \\
\hline S. aureus & $10 \pm 0.52$ & $16 \pm 0.58$ \\
B. subtilis & $10 \pm 0.42$ & $12 \pm 0.43$ \\
E. aerogenes & $10 \pm 0.32$ & $16 \pm 0.53$ \\
E. coli & $7 \pm 0.54$ & $15 \pm 0.23$
\end{tabular}

Table 4: Antibacterial activity of $P$. harmala ethanol extract on the tested bacterial strains. Data are expressed as mean $\pm S D$, where $n=3$.

\begin{tabular}{ccc}
\hline & \multicolumn{2}{c|}{ Zone of inhibition $(\mathrm{mm})$} \\
\cline { 2 - 3 } Bacterial strains & $\begin{array}{c}1000 \mu \mathrm{g} / \mathrm{disc} \\
\text { Mean } \pm \text { SD }\end{array}$ & $\begin{array}{c}2000 \mu \mathrm{g} / \mathrm{disc} \\
\text { Mean } \pm \text { SD }\end{array}$ \\
\hline S. aureus & $7 \pm 0.58$ & $12 \pm 0.21$ \\
B. subtilis & $8 \pm 0.43$ & $20 \pm 0.32$ \\
E. aerogenes & $8 \pm 0.5$ & $17 \pm 0.57$ \\
E. coli & $7 \pm 0.22$ & $15 \pm 0.58$ \\
\hline
\end{tabular}

Table 5: Antibacterial activity of $S$. officinalis ethanol extract on the tested bacterial strains. Mean \pm SD, where $\mathbf{n}=\mathbf{3}$.

\begin{tabular}{ccc}
\hline & \multicolumn{2}{c}{ Zone of inhibition $(\mathrm{mm})$} \\
\cline { 2 - 3 } Bacterial strains & $\begin{array}{c}1000 \mu \mathrm{g} / \mathrm{disc} \\
\text { Mean } \pm \text { SD }\end{array}$ & $\begin{array}{c}2000 \mu \mathrm{g} / \text { disc } \\
\text { Mean } \pm \text { SD }\end{array}$ \\
\hline S. aureus & $13 \pm 0.32$ & $21 \pm 0.35$ \\
B. subtilis & $14 \pm 0.23$ & $20 \pm 0.58$ \\
E. aerogenes & $10 \pm 0.58$ & $16 \pm 0.5$ \\
E.coli & $-\mathrm{ve}$ & $-\mathrm{ve}$ \\
\hline
\end{tabular}

Table 6: Activity of ethanol plant extracts as a free radical scavenger expressed by a Trolox equivalent antioxidant capacity [mg Trolox/g of plant extract].

\begin{tabular}{cc}
\hline Plant & TEAC $_{\mathrm{DPPH}}[\mathrm{mg}$ of Trolox /g of plant extract $]$ \\
\hline P. harmala & $0.67 \pm 0.02$ \\
S. officinalis & $0.53 \pm 0.04$ \\
G. hybridus & $0.89 \pm 0.1$ \\
\hline
\end{tabular}

Correlation between total phenolic content and antioxidant activity obtained by DPPH method.

A weak correlation was found between the phenolic compounds content and antioxidant activity of ethanol plant extracts obtained by DPPHmethod, $\mathrm{R}^{2}=0.6655$.

\section{DISCUSSION}

The selected plants were tested for their activity as antibacterial and antioxidant activity.The results of ethanol crude extract yield of P. harmala, S. officinalis and G. hybridus were $15.6 \%, 10.6 \%, 18 \%$ respectively (table 2). The variation of yield percentages from these plants is due to species and plant parts variation since the same solvent, time and conditions of extraction were used for the three plants. These results are in accordance with other researchers ${ }^{29}$.

The antimicrobial activities of ethanol extracts of these plant were used against two gram negative bacteria: E.coli and E. aerogenes, and two gram positive bacteria: S. aureus, and B. subtilis. The results demonstrated that all these plant ethanol extract have effects on the gram positive strains and gram negative bacteria except $S$. officinalis did not show activity against $E$. coli (Tables 3-6).

The antibacterial effects of $P$. harmala was are in agreement with other investigators results ${ }^{30-33}$. The antibacterial results of $S$. officinalis is in accordance with previous work ${ }^{34-36}$. However, our results disagree with reported research in Brazil who reported that $S$. officinalis was inactive against $S$. aureus and Proteus $s p p^{37}$. The extract from $S$. officinalis showed the maximum zone of inhibition against gram positive bacteria $S$. aureus and the minimum zone of inhibition against gram negative bacteria $E$. coli $^{38}$. The variation between results of S. officinalis is organ and season dependent variation ${ }^{35,39}$.

G. hybridus showed antibacterial activity against both gram positive and gram negative bacteria. This in accordance with other work on the same plant extracts of the same family ${ }^{21,40}$.

Gram-negative bacteria had less susceptibility to the different plant extracts than Gram-positive bacteria. It has been previously shown 
that Gram-negative bacteria are generally more resistant to common antibiotics than Gram-positive ones ${ }^{41}$. Gram-positive bacteria were found to have more susceptibility as compared to Gram-negative bacterial species. This is in agreement with earlier studies which attributed this to the differences in chemical composition and structure of cell wall of both types of microorganisms $\mathrm{s}^{42,43}$. The minimal inhibition concentration (MIC) of P. harmala, S. officinalis and G. hybridus (MIC) ranged from $125 \mu \mathrm{g} / \mathrm{ml}$ to $500 \mu \mathrm{g} / \mathrm{ml}$ (Figure 1). These MIC values are in accordance with antibacterial activity of these plants using the disc diffusion methods.
The antioxidant activity of G. hybridus, P. harmala and S. officinalis was evaluated using the DPPH method. A Trolox standard curve was established using ten concentration of Trolox standard solution ( 0 to 1.5 $\mu \mathrm{g} / \mathrm{ml})$. The antioxidant activity was expressed as Trolox equivalent antioxidant capacity (TEAC) [mg Trolox/g of plant extract] (Table 6). The TEAC for P. harmala S. officinalis and G. hybridus was found $0.67,0.53$ and $0.89 \mathrm{mg} / \mathrm{ml}$ respectively (table 6). It was also found that the plant with the high TPC had the highest TEAC value (Table 6 and Figure 2). The $\mathrm{IC}_{50}$ was also calculated for P. harmala, S. officinalis and $G$. hybridus and it was found 1.1, 1.38 and $0.83 \mathrm{mg} / \mathrm{ml}$ respectively. These

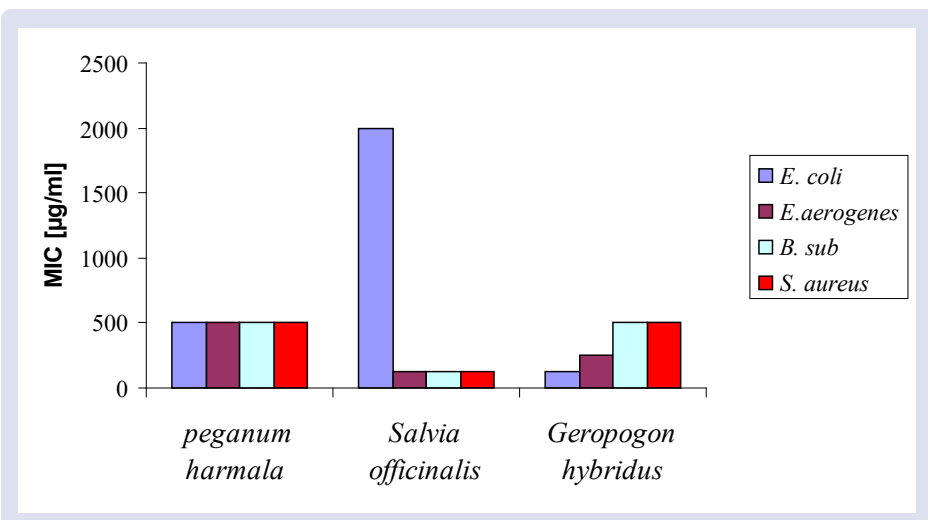

Figure 1: The MIC of ethanol plant extracts on the different bacterial strains.

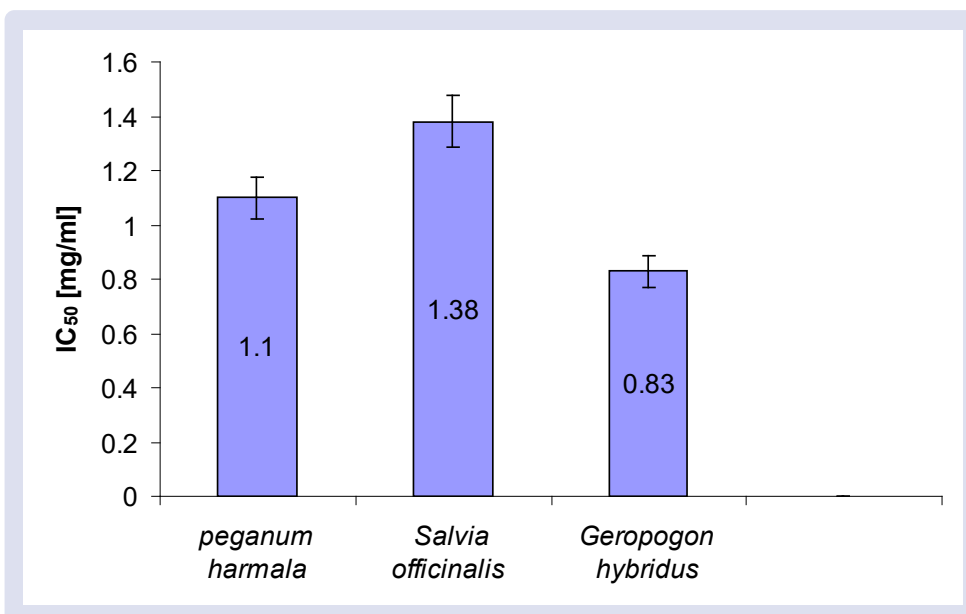

Figure 2: $I C_{50}$ values of four ethanol plant extracts expressed by mean $\pm S D, n=3$.

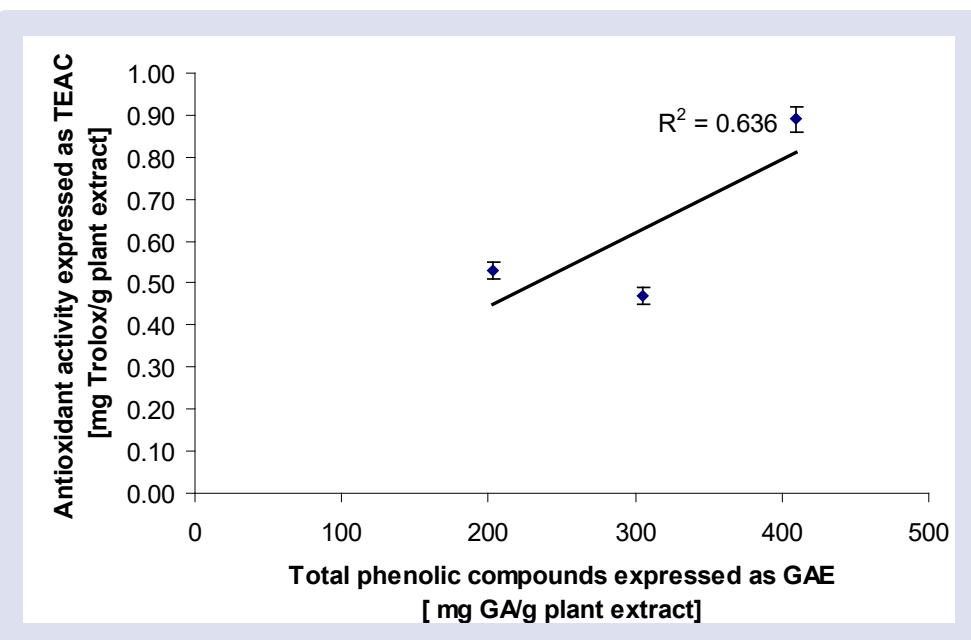

Figure 3: Correlation between TPC and antioxidant activity obtained by DPPH method. 
finding are in accordance with the TPC and TEAC for each plant used in this study. Our results agree with other worker in the field ${ }^{11,21,44,45}$.

Extraction of antioxidant compounds from plant material is dependent on the solubility of these compounds in various solvents. The polarity of solvent used plays a key role in increasing the solubility of these compounds $\mathrm{s}^{46,47}$. The correlation between TPCs and the antioxidant activity based on the DPPH assay involving the three plants was low. The weak correlation between TPCs and antioxidant activity of the plant extracts may due to the low number of plants used in this study. However, other researcher used 24 plant in their study demonstrated high correlation value between the TPC and the TEAC ${ }^{48}$.

\section{CONCLUSION}

The antibacterial and antioxidant activities of the selected plant suggest that these plants may be source of bioactive substances with multifaceted activity, because from the present investigation, it may be concluded that ethanol extracts of the studied species possessed a potential antibacterial activity against the reference strains.

\section{CONFLICTS OF INTEREST}

The authors declare that there are no conflicts of interest.

\section{ACKNOWLEGEMENT}

The authors do thank all the staff in Department of biology, Faculty of Science, Mu tah University, Jordan.

\section{REFERENCES}

1. Bourgaud, F., A. Gravot, S. Milesi, and E. Gontier, Production of plant secondary metabolites: a historical perspective. Plant science, 2001. 161(5): p. 839-851.

2. Chanda, S. and T. Ramachandra, A review on some Therapeutic aspects of Phytochemicals present in Medicinal plants. International Journal of Pharmacy \& Life Sciences, 2019. 10(1).

3. Narmani, A., R.B. Teponno, M. Arzanlou, F. Surup, S.E. Helaly, K. Wittstein, D.F. Praditya, A. Babai-Ahari, E. Steinmann, and M. Stadler, Cytotoxic, antimicrobial and antiviral secondary metabolites produced by the plant pathogenic fungus Cytospora sp. CCTU A309. Fitoterapia, 2019. 134: p. 314-322.

4. Siew, Y.-Y., H.-C. Yew, S.-Y. Neo, S.-V. Seow, S.-M. Lew, S.-W. Lim, C.S.E.-S. Lim, Y.-C. Ng, W.-G. Seetoh, and A. Ali, Evaluation of antiproliferative activity of medicinal plants used in Asian Traditional Medicine to treat cancer. Journal of ethnopharmacology, 2019. 235: p. 75-87.

5. Eatimony, S., K.N. Urmee, N. Ara, and M. Rahmatullah, Using plants as medicines-practices of a female folk medicinal practitioner in Hatirdiya village, Bangladesh. Journal of Medicinal Plants, 2019. 7(1): p. 55-57.

6. Jiang, W., B. Jiang, N. Mantri, Z. Wu, L. Mao, H. Lu, and Z. Tao, Comparative ecophysiological analysis of photosynthesis, biomass allocation, polysaccharide and alkaloid content in three Dendrobium candidum cultivars. Plant Omics, 2014. 7(2): p. 117.

7. Zhang, Y.-J., R.-Y. Gan, S. Li, Y. Zhou, A.-N. Li, D.-P. Xu, and H.-B. Li, Antioxidant phytochemicals for the prevention and treatment of chronic diseases. Molecules, 2015. 20(12): p. 21138-21156.

8. Niu, L., N. Mantri, C.G. Li, C. Xue, and E. Pang, Array-based techniques for fingerprinting medicinal herbs. Chinese medicine, 2011. 6(1): p. 18.

9. Witaicenis, A., L.N. Seito, A. da Silveira Chagas, L.D. de Almeida Junior, A.C. Luchini, P. Rodrigues-Orsi, S.H. Cestari, and L.C. Di Stasi, Antioxidant and intestinal anti-inflammatory effects of plant-derived coumarin derivatives. Phytomedicine, 2014. 21(3): p. 240-246.

10. Huang, D., B. Ou, and R.L. Prior, The chemistry behind antioxidant capacity assays. Journal of agricultural and food chemistry, 2005. 53(6): p. 1841-1856.
11. Tarawneh, K.A., F. Irshaid, A.S. Jaran, M. Ezealarab, and K.M. Khleifat, Evaluation of antibacterial and antioxidant activities of methanolic extracts of some medicinal plants in northern part of Jordan. Journal of biological sciences, 2010. 10(4): p. 325-332.

12. Bhalodia, N.R. and V. Shukla, Antibacterial and antifungal activities from leaf extracts of Cassia fistula I.: An ethnomedicinal plant. Journal of advanced pharmaceutical technology \& research, 2011. 2(2): p. 104.

13. Kumar, V.P., N.S. Chauhan, H. Padh, and M. Rajani, Search for antibacterial and antifungal agents from selected Indian medicinal plants. Journal of ethnopharmacology, 2006. 107(2): p. 182-188.

14. Cox, P.A. and M.J. Balick, The ethnobotanical approach to drug discovery. Scientific American, 1994. 270(6): p. 82-87.

15. Chinsembu, K.C., Ethnobotanical study of plants used in the management of HIV/AIDS-related diseases in Livingstone, Southern Province, Zambia. Evidence-Based Complementary and Alternative Medicine, 2016. 2016

16. Ali-Shtayeh, M.S., R.M. Jamous, J.H. Al-Shafie, W.A. Elgharabah, F.A. Kherfan, K.H. Qarariah, K. Isra'S, I.M. Soos, A.A. Musleh, and B.A. Isa, Traditional knowledge of wild edible plants used in Palestine (Northern West Bank): a comparative study. Journal of Ethnobiology and Ethnomedicine, 2008. 4(1): p. 13.

17. Sha'bani, N., S. Miraj, M. Rafieian-Kohpayei, and A.R. Namjoo, Survey of the detoxification effect of green tea extract on the reproductive system in rats exposed to lead acetate. Advanced biomedical research, 2015. 4.

18. Cunha, A., A. Silva, and O. Roque, Plantas e produtos vegetais em fitoterapia (2 ${ }^{a}$ Edição). Fundação Calouste Gulbenkian, Lisboa, 2006 : p. 31-52.

19. Müller, C.M., B. Schulz, D. Lauterbach, M. Ristow, V. Wissemann, and B. Gemeinholzer, Geropogon hybridus (L.) Sch. Bip.(Asteraceae) exhibits micro-geographic genetic divergence at ecological range limits along a steep precipitation gradient. Plant Systematics and Evolution, 2017. 303(1): p. 91-104.

20. Kilian, N., Flora of the USSR. Vol. 29. Compositae. Tribe Cichorieae. 2001, JSTOR.

21. Acikara, Ö.B., G.S. Çİtoglu, and T. Çoban, Evaluation of antioxidant properties of some tragopogon species growing in turkey. Turkish Journal of Pharmaceutical Sciences, 2013. 10(3).

22. Cichewicz, R.H. and P.A. Thorpe, The antimicrobial properties of chile peppers (Capsicum species) and their uses in Mayan medicine. Journal of ethnopharmacology, 1996. 52(2): p. 61-70.

23. Alzoreky, N. and K. Nakahara, Antibacterial activity of extracts from some edible plants commonly consumed in Asia. International journal of food microbiology, 2003. 80(3): p. 223-230.

24. Zwadyk, P., Enteriobacteriaceae in zinsser microbiology. George Thiene Verlag stuttgart Germany, 1972: p. 20-32.

25. Romero, C.D., S.F. Chopin, G. Buck, E. Martinez, M. Garcia, and L. Bixby, Antibacterial properties of common herbal remedies of the southwest. Journal of ethnopharmacology, 2005. 99(2): p. 253-257.

26. Patel, M.H., A.M. Patel, S.M. Patel, G.L. Ninama, K.R. Patel, and B.C. Lavingia, Antifungal susceptibility testing to determine mic of amphotericine $b$, fluconazole and ketoconazole against ocular fungal infection. Nat J Comm Med, 2011. 2: p. 302-305.

27. Tepe, B., D. Daferera, A. Sokmen, M. Sokmen, and M. Polissiou, Antimicrobial and antioxidant activities of the essential oil and various extracts of Salvia tomentosa Miller (Lamiaceae). Food chemistry, 2005. 90(3): p. 333-340.

28. Jung, H.A., A.R. Kim, H.Y. Chung, and J.S. Choi, In vitro antioxidant activity of some selectedPrunus species in Korea. Archives of pharmacal research, 2002. 25(6): p. 865-872.

29. Ahmadi, Z., M. Sattari, B. Tabaraee, and M. Bigdeli, Identification of the constituents of Achillea santolina essential oil and evaluation of the anti-microbial effects of its extract and essential oil. Arak Medical University Journal, 2011. 14(56): p. 1-10. 
30. Benbott, A., A. Yahyia, and A. Belaidi, Assessment of the antibacterial activity of crude alkaloids extracted from seeds and roots of the plant Peganum harmala L. J. Nat. Prod. Plant Resour, 2012. 2(5): p. 568573.

31. Darabpour, E., A.P. Bavi, H. Motamedi, and S.M.S. Nejad, Antibacterial activity of different parts of Peganum harmala L. growing in Iran against multi-drug resistant bacteria. EXCLI journal, 2011. 10: p. 252.

32. Moghadam, M.S., S. Maleki, E. Darabpour, H. Motamedi, and S.M.S. Nejad, Antibacterial activity of eight Iranian plant extracts against methicillin and cefixime restistant Staphylococcous aureus strains. Asian Pacific Journal of Tropical Medicine, 2010. 3(4): p. 262-265.

33. Mazandarani, M., E. Ghaemi, and F. Ghaffari, Antibacterial survey of different extracts of Peganum harmala L. different parts in North east of Golestan province (Inche Borun). 2009.

34. Liu, Z.-H. and H. Nakano, Antibacterial activity of spice extracts against food-related bacteria. Journal of the Faculty of Applied Biological Science-Hiroshima University (Japan), 1996.

35. Delamare, A.P.L., I.T. Moschen-Pistorello, L. Artico, L. Atti-Serafini, and S. Echeverrigaray, Antibacterial activity of the essential oils of Salvia officinalis L. and Salvia triloba L. cultivated in South Brazil. Food chemistry, 2007. 100(2): p. 603-608

36. Muttalib, L.Y. and A.M. Naqishbandi, Antibacterial and phytochemical study of Iraqi Salvia officinalis leave extracts. Iraqi Journal of Pharmaceutical Sciences (P-ISSN: 1683-3597, E-ISSN: 2521-3512), 2012. 21(1): p. 93-97.

37. Nascimento, G.G., J. Locatelli, P.C. Freitas, and G.L. Silva, Antibacterial activity of plant extracts and phytochemicals on antibiotic-resistant bacteria. Brazilian journal of microbiology, 2000. 31(4): p. 247-256.

38. POP, A.-V., M. TOFANĂ, S.A. Socaci, C. Pop, A.M. ROTAR, M. Nagy, and L. SALANȚĂ, Determination of Antioxidant Capacity and Antimicrobial Activity of Selected Salvia Species. Bulletin UASVM Food Science and Technology, 2016. 73: p. 1.

39. Santos-Gomes, P.C. and M. Fernandes-Ferreira, Organ-and seasondependent variation in the essential oil composition of Salvia officinalis L. cultivated at two different sites. Journal of agricultural and food chemistry, 2001. 49(6): p. 2908-2916.
40. Hasson, R.N., Antibacterial activity of water and alcoholic crude extract of flower Achillea millefolium. Rafidain journal of science, 2011. 22(3E): p. 11-20

41. Cos, P., A.J. Vlietinck, D.V. Berghe, and L. Maes, Anti-infective potential of natural products: how to develop a stronger in vitro 'proofof-concept'. Journal of ethnopharmacology, 2006. 106(3): p. 290-302.

42. Nair, R. and S. Chanda, In-vitro antimicrobial activity of Psidium guajava L. leaf extracts against clinically important pathogenic microbial strains. Brazilian Journal of Microbiology, 2007. 38(3): p. 452-458.

43. Yaghoubi, M., G. Gh, and R. Satari, Antimicrobial activity of Iranian propolis and its chemical composition. DARU Journal of Pharmaceutical Sciences, 2007. 15(1): p. 45-48.

44. Mojarrab, M., A.K. Mohammadi, L. Hosseinzadeh, and Z.M. SiavashHaghighi, Antioxidant activity and safety assessment of Tragopogon buphthalmoides hydroethanolic extract: Acute and subchronic toxicities. Research in pharmaceutical sciences, 2014. 9(5): p. 359.

45. Tenkerian, C., M. El-Sibai, C.F. Daher, and M. Mroueh, Hepatoprotective, antioxidant, and anticancer effects of the tragopogon porrifolius methanolic extract. Evidence-Based Complementary and Alternative Medicine, 2015. 2015.

46. Silva, E., J. Souza, H. Rogez, J.-F. Rees, and Y. Larondelle, Antioxidant activities and polyphenolic contents of fifteen selected plant species from the Amazonian region. Food Chemistry, 2007. 101(3): p. 1012 1018 .

47. Kooti, W., Z. Hasanzadeh-Noohi, N. Sharafi-Ahvazi, M. AsadiSamani, and D. Ashtary-Larky, Phytochemistry, pharmacology, and therapeutic uses of black seed (Nigella sativa). Chinese journal of natural medicines, 2016. 14(10): p. 732-745.

48. Piluzza, G. and S. Bullitta, Correlations between phenolic content and antioxidant properties in twenty-four plant species of traditional ethnoveterinary use in the Mediterranean area. Pharmaceutical biology, 2011. 49(3): p. 240-247. 


\section{GRAPHICAL ABSTRACT}
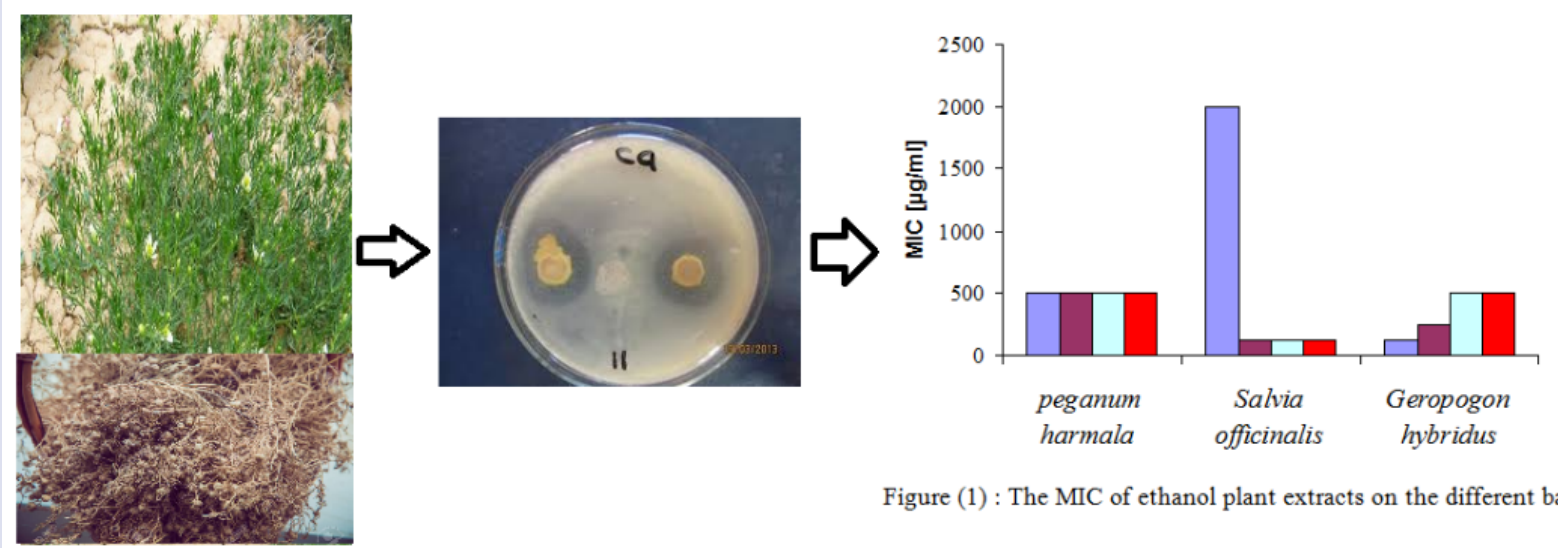

Figure (1) : The MIC of ethanol plant extracts on the different bacterial strains

\section{ABOUT AUTHORS}

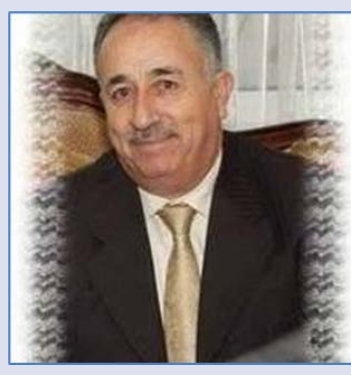

Khaled Ahmed Tarawneh was born in Al-Karak (Jordan) in 1949. He received his Ph.D. in Molecular biology in 1989 from State University of New York (United states). He holds a full professor position and his main research interests in Molecular biology and microbiology. He has established an advanced research laboratory, emphasizing on molecular studies. Over 50 papers in $\mathrm{SCl}$ ranked journals and conference, including more than 5 invited in major international conferences, and he has one patent. He has nearly 29 years of professional experience in different fields of academic and administration. After serving in Jordan as Vicepresident at Mutah university and as Dean of science and agricultural faculties.

B.A .Besancon University. 1975. France. Biology

M.A .State University of New York 1988. USA. Molecular biology

Ph.D State University of New York. 1989. US. Molecular biology

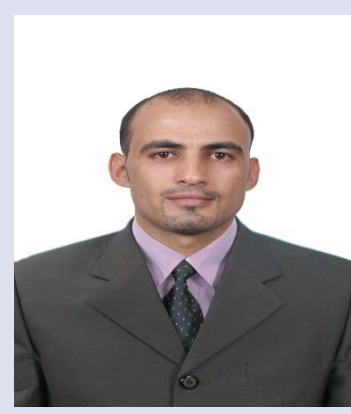

Prof. Dr. Ali Alqudah is Assistant Professor at the department of applied biology of the Tafila Technical University. He received his Ph.D. Biotechnology in 2017 from the International Islamic University Malaysia. He is the author or coauthor of more than 20 papers in international refereed journal and his research interests cover several aspects of Biotechnology, Microbiology and Biochemistry. He currently serves as Head of Department and teaches several topics including genetic, ecology and forensic science.

Ph.D., Biotechnology, International Islamic University Malaysia

M.S., Biology, Mu`tah University

B.A., Biology, Mu`tah University

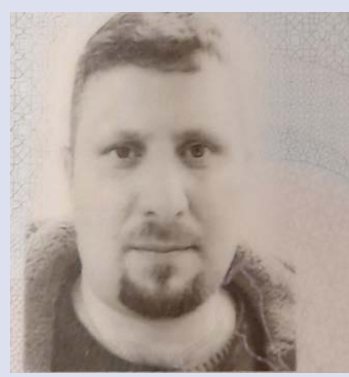

Waleed Alany was born and raised in Iraq, and he is a master student in Mu'tah University. Throughout his education, he always on the honor roll and received numerous awards for academic achievement. After graduating from high school with high honors, he went on to pursue my biology degree at Mu'tah University. His interest in microbiology research and currently works as a lecturer in Mu'tah University.

M.S., Biology, Mu'tah University

B.A., Biology, Mu`tah University

Cite this article: Alani WK, Alqudah AA, Tarawneh KA. Antibacterial and Antioxidant Activities of Ethanol Extracts of Some Plants Selected from South Jordan. Pharmacog J. 2021;13(2): 528-34. 